50 p.p.b. in water throughout the United States, experts say, and can rise to several parts per million in agricultural run-off.

Amphibians are highly sensitive to pollutants and are regarded as 'sentinel' species that can provide the first indications of damage to an ecosystem. Hayes's results come as the US Environmental Protection Agency (EPA) is re-evaluating the risks posed by atrazine - following a 1999 ruling on a lawsuit from the Natural Resources Defense Council and other environmental groups, requiring the agency to accelerate its efforts to reassess the environmental and health risks posed by a range of potential

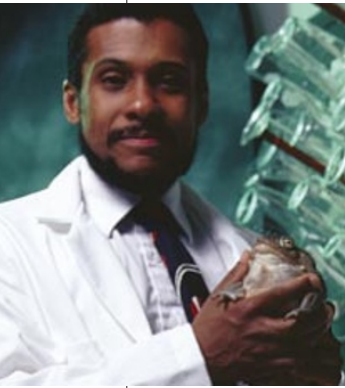
endocrine disrupters.

The EPA currently allows levels of atrazine to reach 3 p.p.b.in US drinking water. An EPA panel will hold a public meeting this week in Arlington, Virginia, on suggested residue levels of atrazine in food products.

Hayes has provided Tyrone Hayes has the EPA with a report on fears for frogs. his unpublished fieldwork on frogs from

Colorado to Wisconsin, but EPA officials declined to comment on this, or on Hayes's newly published paper. The agency aims to issue final reports on the risks posed by atrazine by August.

Atrazine is manufactured by Syngenta of Basel, Switzerland. Alan Hosmer, Syngenta's manager of ecological sciences in Greensboro, North Carolina, says that the firm is aware of some of Hayes's results. But the company failed to provide a detailed statement before Nature went to press. For three years, Hayes worked on contract research at Berkeley for Syngenta. But he severed relations with the firm last year, independently pursuing the studies that led to this week's paper.

Aside from their implications for the use of atrazine in the United States and elsewhere, Hayes's results add another element to the debate over why amphibian populations are declining across the world. Many factors are thought to be involved, including pathogens, pollution, competition with invading alien species, and habitat loss.

James Hanken, a herpetologist at Harvard University who chairs the international Declining Amphibian Populations Task Force, describes Hayes's results as "compelling". But he notes that some of the most severe declines are in Central America, where atrazine is not thought to be widely used. Hanken argues that further studies are needed to determine what role atrazine and related chemicals are playing in amphibian declines across the globe.

www.open.ac.uk/daptt

\title{
Parkinson's patients show positive response to implants
}

\section{Erika Check, Washington}

Fetal cells transplanted into the brains of patients with Parkinson's disease can survive and mature for up to eight years after the surgery, helping to alleviate the debilitating tremors seen in the disease. These positive results, from a trial that last year attracted controversy because of the side-effects experienced by a small number of patients, should help to lift the cloud that has since hung over cellular therapies for the condition.

Parkinson's is caused by the death of cells that secrete the neurotransmitter dopamine. When Curt Freed of the University of Colorado and his colleagues reported on the trial last year, their results confirmed that transplanted cells from the brains of aborted fetuses can help to relieve the symptoms of the disease (see Nature 410, 401; 2001). But five of the 20 patients treated experienced jerky, uncontrolled movements called dyskinesias.

This week, at a meeting of the American Academy of Neurology in Denver, Colorado, Freed reported that these patients have since responded to treatment aimed at addressing this unwanted side-effect either by giving them drugs to remove excess dopamine or by implanting a device called a 'deep-brain stimulator', which delivers timed electric shocks to the brain region that causes the dyskinesias. Indeed, one of the dyskinetic patients was working in the World Trade Center at the time of the 11 September attacks last year, and was able to make his escape by walking down 33 flights of stairs.

The new results are from a total of 32 patients. The trial was expanded by relaxing its double-blind design and allowing some patients who had initially been in the control group to have the transplants. The degree of improvement varied between patients, but seemed to be independent of age - the team's earlier data had suggested that only those younger than 60 benefited. Patients who did best were those who had previously responded most strongly to the drug L-DOPA, which is converted to dopamine in the brain.

Autopsies on three patients who died up to eight years after surgery showed that the transplanted fetal cells were making increasing amounts of a pigment called neuromelanin. Neurons make neuromelanin as they age. "This says the dopamine neurons we've transplanted appear to be developing as though they were in normal human brain environments," says Freed.

This result is particularly encouraging, says Ole Isacson, a Parkinson's expert at

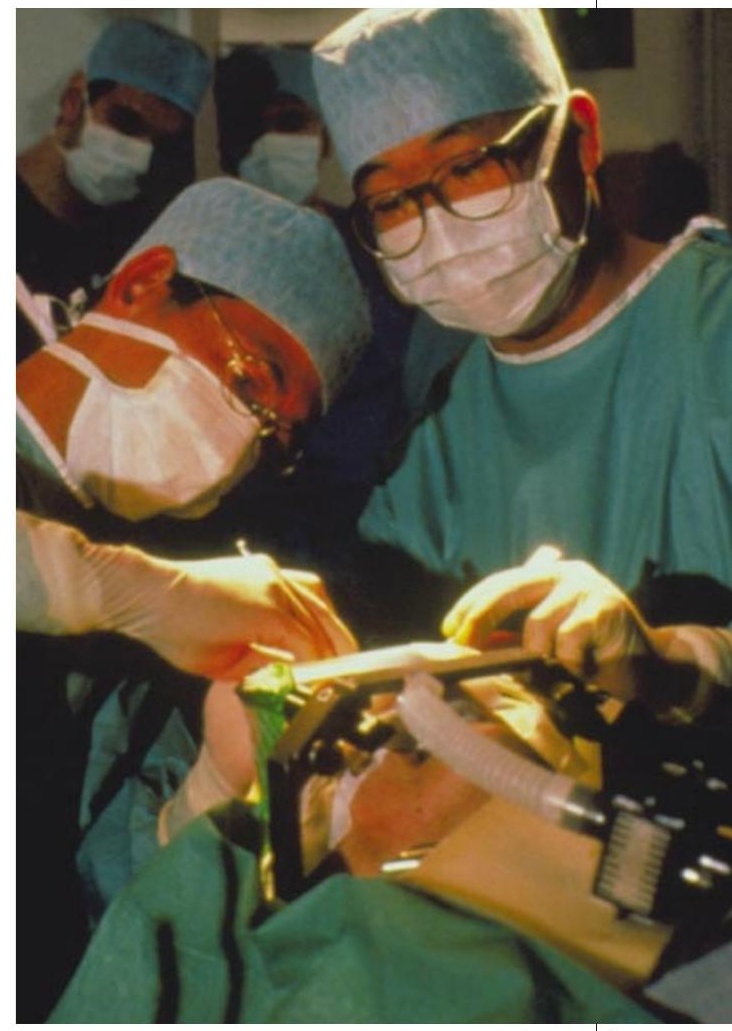

Fetal cells transplanted into the brains of patients with Parkinson's can ease the disease's symptoms.

Harvard Medical School. "Maturation is the key," he says. "These grafts need to grow and mature to become effective."

But Isacson and other researchers say that cellular therapies will need further refinement if they are to deliver better results than conventional drug therapy. They note that Freed's team transplanted cells into a brain structure called the putamen, which contains the cells that respond to dopamine. But Ivar Mendez, a neurosurgeon at Dalhousie University in Halifax, Nova Scotia, has begun a pilot study in which five patients have received fetal-cell transplants into both the putamen and the substantia nigra - the structure that contains the dopaminesecreting cells lost in Parkinson's.

Mendez also treats fetal cells with a biochemical called glial-cell-line-derived neurotrophic factor before transplanting them. A brain-imaging study indicates that these treated cells survive better in their new environment. Mendez's patients also seem to improve faster than those in Freed's trial.

Other groups, meanwhile, are working on techniques to grow dopamine-producing neurons from cultures of human embryonic or adult neural stem cells, which would remove the need to obtain material from freshly aborted fetuses. 